radicals with that of TAN, which was synthesised according to the method described by Rozantsev ${ }^{13}$. As seen from Table 1 the linewidth, the $g$-factor and the nitrogen splitting of the photoproduced radical and those of TAN are identical within the error limits.

The photo-induced yield of radicals was about 10 times higher in $\mathrm{D}_{2} \mathrm{O}$ than in $\mathrm{H}_{2} \mathrm{O}$. This confirms our assumption that the radicals are produced by a singlet oxygen pathway as the lifetime of ${ }^{1} \mathrm{O}_{2}$ is 10 times longer in $\mathrm{D}_{2} \mathrm{O}$ than in $\mathrm{H}_{2} \mathrm{O}$ (ref. 14). Furthermore, this shows that $0.02 \mathrm{M} 2,2,6,6$-tetramethyl-4-piperidone does not reduce the lifetime of ${ }^{\prime} \mathrm{O}_{2}$ even in $\mathrm{D}_{2} \mathrm{O}$. Thus the method is convenient for studying the effect of singlet oxygen quenchers.

When using this method to monitor singlet oxygen yields in different aqueous solutions $p \mathrm{H}$ as well as the temperature of the solutions should be carefully controlled. The temperature dependence of the yields follows the Arrhenius equation between 5 and $40^{\circ} \mathrm{C}$. An activation energy of $12.5 \mathrm{kcal} \mathrm{mol}^{-1}$ may be estimated for the reaction of singlet oxygen with 2,2,6,6tetramethyl-4-piperidone $(0.3 \mathrm{M}$ at $\mathrm{pH}=7.4)$. Furthermore, one should be aware that any strong oxidising agent may produce the radical: for example when TAN is synthesised from 2,2,6,6-tetramethyl-4-piperidone, $\mathrm{H}_{2} \mathrm{O}_{2}$ is used as the oxidising agent ${ }^{13}$. Hence, in systems where many oxidants are likely to be produced one should compare the yields with $\mathrm{H}_{2} \mathrm{O}$ and $\mathrm{D}_{2} \mathrm{O}$ as solvents to verify that radical production takes place through singlet oxygen.

The sensitivity of the method was estimated as follows: Using a known concentration of TAN as a standard and determining the light intensity $(\lambda=405 \mathrm{~nm})$ by means of a calibrated YSI Kettering Model 65A radiometer we were able to estimate the quantum yield of photo-produced radicals to $5 \times 10^{-4}$ in a solution of $0.3 \mathrm{M} 2,2,6,6$-tetramethyl-4-piperidone and $10^{-4} \mathrm{M}$ haematoporphyrin $(p \mathrm{H}=7.4)$. Before irradiation about $4 \times$ $10^{-7} \mathrm{M}$ radicals were present in the samples as an impurity. To produce an additional $4 \times 10^{-7} \mathrm{M}$ radicals in an ESR sample of $0.2 \mathrm{ml}$ a light dose of $50 \mathrm{~mJ}$ must be absorbed in the sample. The sensitivity of our ESR spectrometer allows detection of $10^{-8} \mathrm{M}$ TAN so one could, in principle, detect an absorbed dose of $1.3 \mathrm{~mJ}$ provided one could get rid of the background signal by purifying the amine.

These doses may be compared with biologically relevant doses. The $D_{37}$ dose for inactivation of NHIK 3025 cells, which originate from a human carcinoma in situ, is about $1 \mathrm{~J} \mathrm{~cm}^{-2}$. This refers to cells growing in tissue culture flasks being irradiated $(\lambda=405 \mathrm{~nm})$ in the presence of $4 \times 10^{-4} \mathrm{M}$ haematoporphyrin in E2a medium (J.M., unpublished results). Light doses proposed for phototherapy of cancer are of the order of $120 \mathrm{~J} \mathrm{~cm}^{-2}$ (ref. 15). Thus in such conditions the method of detecting singlet oxygen by means of its reaction with 2,2,6,6-tetramethyl-4piperidone has a sensitivity which is more than adequate.

\section{JOHAN MOAN}

Norsk Hydro's Institute for Cancer Research,

\section{EINAR WOLD}

The Norwegian Radiumhospital,

Montebello, Oslo 3, Norway

Received 22 January; accepted 10 April 1979

Kearns. D. R. Chem. Rev. 71, 395-427 (1971).

Khan. A J phys Chem 80, 2219-2227 (1976)

3. Rosenthal, I. Photochem. Photobiol. 24, 641-645 (1976).

4. Spikes, J. D. in The Science of Photobiology (ed. Smith, K. C.) 87-112 (Plenum, New York, 1977)

5. Wallis, C. \& Melnick, J. L. Photochem. Photobiol. 4, 159-170)(1965)

6. Giranclli, S., Diamond, I., McDunagh, A., Wilson, C. \& Niclsen, S. Cancer Res. 35, 2567-2570 (1975).

7. Dougherty, T. J., Grindey, G., Fiel. R., Weishaupt. K. \& Boyle, D. J. natn. Cancer Inst. 55, $115-121$ (1975).

8. Foote, C. S. in Free Radicals in Biology (ed. Pryor, W. A.) 85-133 (Academic, New York. 1976 .

9. Goldstein, B. D. \& Harber, L. C. J. clin. Invest. 51, 892-9()2 (1972).

10. Lion, Y., Delmelle, M., \& Van de Vorst, A., Nature 263, 442-443(1976)

1. Weishaupt, K. R., Gomer, C. J. \& Dougherty. I. J. Cancer Res. 36, 2326-2329 (1976).

12. Moan, J., Pettersen, E. O. \& Christensen, T. Br. J. Cancer (in the press).

13. Rivantsev, E. G. Free Nitroxyl Radicals, 213-214 (Plenum. New York. 1970).

14. Merkel, P. B. \& Kearns, D. R. J. Am. chem. Soc. 94, 7244-7352 (1972).

15. Dougheriy. I. J et al. Cancer Res. 38. 2628-2635 (1978).

\section{Corrigenda}

In the letter 'Viroid replication is inhibited by $\alpha$-amanitin' by $E$. W. Ferguson and G. E. Sanger, Nature 278, 185, the values for $\alpha$-amanitin concentration on Fig. 2 are incorrect. The figure is reproduced correctly below.

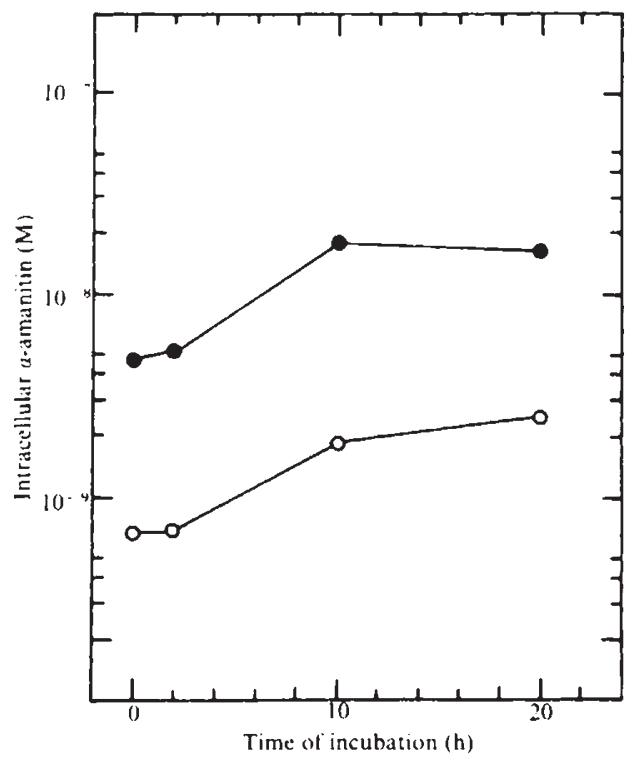

In the article 'Bursal dissections and gill pouch hormones' by J. W. Shields, Nature 259, 373-376 (1976), the following items on page 374 (column 2) should be amended:

(1) In line 1 , for surgical bursectomy read testosterone bursectomy.

(2) In section (4) it was stated that birds also differ from mammals because avian neonates lack immunoglobulins from maternal milk. This is true in precocial hatchlings (such as chicks), but is not true for altricial nestlings (such as pigeons) which feed until nidifugation on regurgitated parental cropsac milk ${ }^{1}$. The 'pigeon's milk' is produced in parental pharyngeal mucous glands containing tonsillar tissue; it looks like mammalian colustrum; and apparently compensates for the atrophic cloacal bursae of Fabricius in altricial nestlings ${ }^{2}$.

1. Weliy, J. C. The Life of Birds (Saunders, Philadelphia, 1975).

2. Shiclds, J. W., Dickson, D. R., Abbott, W. \& Delvin, J. Devl comp. Immun. 3, 5-22 (1979)

\section{Erratum}

In the letter 'Highly efficient quantum conversion at chlorophyll $a$-lecithin mixed monolayer coated electrodes' by Miyasaka et al., Nature 277, 638-640, Table 1 (shown below) was omitted.

\begin{tabular}{|c|c|c|c|c|c|}
\hline \multirow{2}{*}{$\begin{array}{l}\text { Molar ratio } \\
\text { Chl a/DPL }\end{array}$} & \multirow{2}{*}{$\begin{array}{c}\text { Mean (.hl } a-C h \text { la } a \\
\text { intermoiecular } \\
\text { distance }(\AA)\end{array}$} & \multirow{2}{*}{$\begin{array}{l}\text { Absurbance } \\
\text { per layer" } \\
\text { in red band }\end{array}$} & \multicolumn{2}{|c|}{$\begin{array}{l}\text { Peak positions } \\
\text { of photocurrents } \\
\text { (nm) }\end{array}$} & \multirow{2}{*}{$\begin{array}{l}\text { Photocurrent } \\
\text { efficiency } \\
\text { in red band } \neq \\
(\%)\end{array}$} \\
\hline & & & Red & Blue & \\
\hline $1 / 0$ & 10 & 0.0082 & 675 & 415 & 6 \\
\hline $2 / 1$ & 12 & 0.0060 & 675 & 415 & 8 \\
\hline $1 / 1$ & 12 & 0.0058 & 675 & 412 & 10 \\
\hline $1 / 2$ & 13 & 0.0047 & 675 & 415 & 9 \\
\hline $1 / 4$ & 17 & 0.0031 & 675 & 415 & 8 \\
\hline $1 / 9$ & 24 & 0.0018 & 673 & 418 & 10 \\
\hline $1 / 19$ & 36 & 0.0008 & 673 & $410-420$ & $14 \pm 2$ \\
\hline $1 / 49$ & 56 & $0.060) 3$ & 666 & 420 & $25 \pm 5$ \\
\hline $1 / 99$ & 83 & 0.0002 & 670 & 425 & $25 \pm 5$ \\
\hline
\end{tabular}

- Conditions of mcasurements: electrolyte composition, $0.05 \mathrm{M} \mathrm{H}_{2} \mathrm{Q}, 0.1 \mathrm{M} \mathrm{Na} \mathrm{SO}_{4}$ and phosphate buffer ( $\mathrm{pH} 6.9)$; electrode potential, $0.1 \mathrm{~V}$ vs $\mathrm{SCE}$; surface pressure for monolayer deposition, 20 dyn $\mathrm{cm}$

+ Measured at OTE-air interface.

In the absence of $\mathrm{H}_{2} \mathrm{O}$ the quantum efficiency measured at $0.6 \mathrm{~V}$ vs SCE in neutral electrolyte solution was about $1.5 \%$ for a mixed monolayer of $\mathrm{Chl} a / \mathrm{DPL}(1 / 1)$ 